z którą zasiedzenie nie wygasza obciążeń własności (jako że jest skierowane wyłącznie przeciw właścicielowi), Autor proponuje zapisy (zob. wyżej) w większym stopniu uwzględniające wymogi logiki oraz fakt, iż chodzi tu o postać pierwotnego nabycia prawa własności.

Lektura książki A. Rudokwasa prowadzi do wniosku, że mamy do czynienia z interesująca i wartościową pozycją. W moim przekonaniu, Autorowi udało się zrealizować zakładany cel, a mianowicie: na podstawie obcych doświadczeń wypracować rozwiązania pod wieloma względami lepsze od pierwowzoru.

Leopold Moskwa

\title{
Radosław Pastusiak, Specjalne strefy ekono- miczne jako stymulator rozwoju gospodarczego, Wydawnictwo Uniwersytetu Łódzkiego, Łódź 2011, ss. 357.
}

Książka Radosława Pastusiaka jest bardzo rozbudowaną monografią, liczącą 357 stron, podejmująca problematykę powstawania, funkcjonowania i konsekwencji działania specjalnych stref ekonomicznych, z położeniem nacisku na Polskę. Całościowa, ogólna ocena pracy Specjalne strefy ekonomiczne jako stymulatory rozwoju gospodarczego jest pozytywna. Niemniej praca nie jest wolna od słabszych stron. Mocne i słabe strony pracy wzajemnie się przeplatają.

Po pierwsze, silną stroną opracowania jest zajęcie się ważną problematyką. Jej doniosłość dobrze wpisuje się $\mathrm{w}$ prowadzoną ze szczególnym zainteresowaniem $\mathrm{w}$ okresie kryzysu debatę na temat granic pożądanej interwencji państwa $\mathrm{w}$ gospodarkę, w tym udzielanej przedsiębiorstwom pomocy publicznej. Jest to jednocześnie tematyka aktualna $\mathrm{w}$ związku z postępującymi procesami internacjonalizacji i globalizacji oraz potrzebą prowadzenia porównań międzynarodowych $\mathrm{w}$ tym zakresie. Ponadto należy zwrócić uwagę na różnorodność, a często rozbieżność poglądów w tej materii spotykaną w literaturze, co sprawia dodatkowy kłopot badaczom podejmującym studia w tym rozległym i trudnym obszarze badawczym.

Po drugie, mocna strona pracy jest szeroki merytorycznie i rozbudowany metodologicznie zakres przyjętego celu badawczego. Podjęcie się zadania wytyczonego w pracy wymagało od Autora z pewnością dużej odwagi badawczej. Obszar prowadzonych studiów jest bardzo szeroki. Ta ostatnia opinia znajduje potwierdzenie w sposobie sformułowania celu pracy, który został określony następująco: „Zasadniczym celem rozprawy jest przedstawienie specjalnych stref ekonomicznych jako narzędzia wspomagającego rozwój gospodarczy. Takie sformułowanie celu ma za zadanie uwypuklić interakcje finansowe przedsiębiorstw działających w SSE z gospodarką. Dzięki niemu zostana również podjęte próby analizy efektywności inwestycji w gospodarce jako stymulatora rozwoju gospodarczego" (s. 10). Przywołany cel pracy można ocenić jako ambitny. Dodatkowo w pracy podjęto się realizacji celu o charakterze praktyczno-normatywnym - celem tym jest: ,,[...] sformułowanie rekomendacji w zakresie prowadzenia polityki gospodarczej skutecznie wykorzystującej SSE do realizacji założonych zadań" (s. 10). Z przytoczonymi celami związane są hipotezy badawcze przyjęte w opracowaniu. Jak pisze Autor: „Główna hipoteza badawcza przyjęła postać stwierdzenia: Specjalne strefy ekonomiczne sprzyjaja rozwojowi gospodarczemu”. Tak kategoryczne sformułowanie hipotezy jest dyskusyjne. Stoi w sprzeczności z wynikami niektórych badań. Wydaje się, że budowanie hipotezy powinno iść w kierunku jej osłabienia, zrelatywizowania. Hipoteza mogłaby przyjąć postać: „Przy spełnieniu określonych warunków specjalne strefy ekonomiczne mogą sprzyjać rozwojowi gospodarczemu". Jednym z zadań badawczych mogłoby wówczas być sporządzenie katalogu warunków (okoliczności) sprzyjających uzyskiwaniu pozytywnego oddziaływania SSE na rozwój gospodarczy. Dodatkowo Autor napisał:

W celu rozbudowania wnioskowania postawiono sześć hipotez cząstkowych, które sformułowano w sposób następujący:

1. SSE stymulują inwestycje.

2. SSE sa atrakcyjnym miejscem inwestowania, zwłaszcza dla przedsiębiorstw nowych technologii.

3. Głównym zadaniem SSE jest stworzenie nowych miejsc pracy. 
4. SSE wspierają konkurencyjność regionu.

5. Modele szacowania wpływu SSE na rozwój gospodarczy stanowią wartościowy sposób pomiaru efektywności funkcjonowania SSE.

6. SSE na terenie Polski generują dodatnie przepływy pieniężne dla polskiej gospodarki.

Podobnie jak w wypadku głównej hipotezy należy tutaj zakwestionować kategoryczność i bezwarunkowość zapisanych stwierdzeń/przypuszczeń. W zaproponowanych sformułowaniach dostrzegalna jest swego rodzaju fascynacja Autora możliwościami SSE. Wiadomo tymczasem, że w rzeczywistości istnienie stref prowadzi do efektów, które niejednokrotnie oceniane sa niejednoznacznie, a nawet negatywnie. Gdyby SSE były „dobre na wszystko”, to najlepszym rozwiazaniem byłoby prawdopodobnie uczynienie z gospodarki polskiej jednej wielkiej SSE.

Po trzecie, należy zwrócić uwagę na kolejną silną stronę ocenianej książki, którą jest jej układ. Praca składa się ze wstępu, czterech rozdziałów, podsumowania, bibliografii i załączników. Wstęp obejmuje wszystkie niezbędne elementy. Zawiera jasno napisane uzasadnienie wyboru problematyki badań, prezentuje cele postawione pracy oraz przedstawia listę przyjętych hipotez badawczych wraz z dość szerokim ich omówieniem. We wstępie streszczono również zawartość poszczególnych rozdziałów książki. Jeśli chodzi o zasadniczy układ pracy (nazwy, treści, strukturę wewnętrzną oraz sekwencję poszczególnych czterech rozdziałów pracy), to nie budzi on większych wątpliwości i w pełni zasługuje na wysoką ocenę. Należy podkreślić, że przyjęty tok rozumowania, odzwierciedlony w tytułach i zawartości poszczególnych rozdziałów, jest jasny i zrozumiały. Syntetycznie strukturę książki można ująć jako sekwencję czterech zagadnień - rozwój gospodarczy a polityka ekonomiczna państwa, specjalne strefy ekonomiczne jako instrument polityki gospodarczej, specjalne strefy ekonomiczne w Polsce oraz efekty rozwojowe specjalnych stref ekonomicznych w Polsce. W mojej ocenie zarysowany układ pracy klarownie, prosto i przekonująco oddaje najważniejsze aspekty funkcjonowania specjalnych stref ekonomicznych w niektórych regionach/państwach świata oraz w Polsce. W rozdziale pierwszym Autor zawarł ogólne uwagi na temat polityki gospodarczej, następnie zaprezentował pięć grup stymulatorów rozwoju gospodarczego, a ostatni podrozdział poświęcił zagadnieniu inwestycji i ich roli w gospodarce. W rozdziale drugim zamieszczono omówienie genezy SSE, powstanie i rozwój SSE, zachęty dla inwestorów stosowane w SSE w wybranych krajach, znaczenie SSE w stymulowaniu rozwoju gospodarczego wybranych krajów oraz modele szacowania wpływu specjalnych stref ekonomicznych na wzrost gospodarczy. W rozdziale trzecim skoncentrowano uwagę na trzech aspektach SSE: funkcjonowanie w Polsce, charakterystyka polskich SSE oraz przedsiębiorstwa inwestujące w polskich SSE. Czwarty, ostatni rozdział został poświęcony analizie wpływu polskich SSE na wzrost gospodarczy kraju i regionów. Podsumowanie pracy zawiera prezentację wniosków z rozważań prowadzonych w poszczególnych rozdziałach.

Po czwarte, ważną, odrębną w pewnym sensie, silną stroną rozprawy jest jej podbudowa bibliograficzna. Bibliografia pracy nie jest szczególnie rozbudowana, ale zawiera trafnie dobrane najważniejsze pozycje literatury światowej i polskiej wiążące się z podjętymi rozważaniami. Niemniej zdarzyły się tutaj pewne przeoczenia - dziwi na przykład niezauważenie przez Autora pracy Andrzeja Cieślika Geografia inwestycji zagranicznych: Przyczyny i skutki lokalizacji spótek $z$ udziatem kapitatu zagranicznego w Polsce (Wydawnictwa Uniwersytetu Warszawskiego, Warszawa 2005). W książce tej zaprezentowano interesujące wyniki badań dotyczących lokalizacji zagranicznych inwestycji bezpośrednich w specjalnych strefach ekonomicznych w Polsce.

Po piąte, szczególnie wartym zauważenia osiąnięciem recenzowanej książki jest podjęcie w rozdziale czwartym próby określenia wpływu polskich SSE na wzrost gospodarczy kraju i regionu. $\mathrm{Na}$ pozytywną ocenę zasługują zarówno metodyka, przedmiot, jak i skala zrealizowanych badań. Należy tutaj podkreślić, że oceny prezentowane przez Autora są dalekie od jednostronności, co do której przypuszczenia pojawiły się przy omawianiu hipotez zawartych we wstępie pracy. Przeciwnie, prezentowane oceny bazują na uwzględnieniu wielu metod i źródeł oraz w pełni zasługują na stwierdzenie, że sa wyważone.

Po szóste, z czysto edytorskiego punktu widzenia na podkreślenie zasługuje dążenie Autora do prowadzenia przejrzystego wywodu i do syntezy prezentowanych argumentów w formie tabelarycznej lub rysunkowej. Posługuje się On tymi narzędziami w sposób powściagliwy i uzasadniony.

Zgłoszone uwagi krytyczne i sugestie mają częściowo dyskusyjny charakter i nie wpływaja na istotne obniżenie wysokiej oceny książki. W konkluzji należy stwierdzić, że ogólna, całościowa oceny pracy R. Pastusiaka wypada pozytywnie - niżej wyszczególniono przesłanki tej oceny: 
- podjęcie problemu badawczego, który jest istotny zarówno z teoretycznego (poznawczego), jak i z praktycznego (normatywnego) punktu widzenia,

- podjęcie problemu badawczego, który jest postrzegany jako trudny i ambitny,

- zasadny wybór podstaw teoretyczno-metodologicznych prowadzonych rozważań -Autor słusznie przyjął, że zagadnienie SSE jest szczególnym przypadkiem polityki gospodarczej państwa,

- poprawna identyfikacja i umiejętne wykorzystanie światowej i polskiej literatury przedmiotu,

- właściwy układ pracy pod względem zawartości, sekwencji oraz liczby rozdziałów i podrozdziałów,

- uzyskanie znaczących rezultatów badawczych - na szczególną uwagę zasługuja wyniki szacowania wpływu SSE na rozwój gospodarczy w Polsce.

Marian Gorynia m.gorynia@ue.poznan.pl 